\title{
A Common Core of Theosophy in Celtic Myth, Yoga, and Tibetan Buddhism: Walter Y. Evans-Wentz and the Comparative Study of Religion
}

\author{
Imgination is the greatest of magicians. \\ (John Woodroffe, Foreword, Tibetan Book of the Dead)
}

\begin{abstract}
The contribution will discuss the impact of American Theosophist Walter Yeeling Evans-Wentz (1878-1965) on the emerging "science of religion." Evans-Wentz first pursued Celtic studies, concluding in his The Fairy-Faith in Celtic Countries. Here, in line with Theosophical doctrines and Psychical Research, he claimed a "Fairyland" as "a supernormal state of consciousness into which men and women may enter temporarily in dreams, trances, and in various ecstatic states." "Fairies" are nothing less than the "intelligent forces now recognized by psychical researchers." Already in his early work, he drew freely on various other religious traditions in comparative perspective, aiming to corroborate evidence that the idea of rebirth has been advanced as a "common core" of the earliest strand of esoteric traditions. Later, he became attracted to Indian Yoga traditions, and, after periods of intensive practice and study in India, published a translation and commentary of the Tibetan Book of the Dead (1927). Being the first translation into a Western language, this work was a ground-breaking contribution, yet loaded with Theosophical ideas projected into Tibetan Buddhism. An esoteric reading of the Book, Evans-Wentz argued, offers an almost scientific proof of reincarnation, but also a theory of karmic hallucinations that helped to explain cultural variants of after-death imagery. However, even though Evans-Wentz did offer an array of comparative remarks, he never advanced a methodology or system of religious thought, ritual, or a history of religion that overcomes the speculative assumptions of Theosophy. Therefore, the contribution argues that the innovative aspect of Evans-Wentz' studies should be seen in his appreciation of informants belonging to the respective traditions, but also in being a catalyzer for the emerging field of the study of esoteric traditions of Tibetan Buddhism.
\end{abstract}




\section{Introduction}

Western occultism and esotericism were, according to the guiding hypothesis of the conference, one of the fertile grounds that nourished an academic interest in comparative religion. As such, several scholars of the Occult in the late $19^{\text {th }}$ and early $20^{\text {th }}$ centuries were - directly or indirectly - involved in the emergence of "comparative religion," or Religionswissenschaft, as an academic discipline. In this line, the approach of Walter Yeeling Evans-Wentz (1878-1965) will be in the focus of this contribution. Although his books have been popular for almost a century now, his impact on the comparative study of religion has never been made the topic of an extensive study. The same holds true for studies of the history of the Theosophical movement, ${ }^{1}$ or those dealing with the Western reception of Buddhism, and even in historiographies of the academic study of Buddhism, he is hardly ever discussed to a greater extent. As will be argued below, the reason for this negligence is the idiosyncratic, unconventional nature of Evans-Wentz' work. For some Theosophists, his interest in Celtic literature, Tibetan Buddhism, and Neo-Hinduism was, I assume, probably too nonpartisan, while Tibetologists were soon dissatisfied with his inaccurate translation and esoteric commentaries. For proponents of the academic discipline of comparative religion, however, though they made extensive use of his works, the absence of attempts to systematize the material, in combination with his highly speculative thoughts on the common heritage of Occidental and Oriental esotericism, was seemingly the most substantial impediment - even for scholars in the tradition of the phenomenology of religion.

So far, contributions on Evans-Wentz focused almost exclusively on his "pioneer role" in the study of Tibetan Buddhism in general, and Buddhist Tantrism such as the teachings of the liberation while in the Bar-do of the so called The Tibetan Book of the Dead in particular. This pioneer role has best been summarized by John Strong. Referring to the mid-1960, he comments that Tibet, at that time, "was still an academic terra incognita," and he continues: "as I sometimes joke - not completely accurately - to the students in my Tibetan religions class: 'when I was in college, there were only four books in English in Tibetan Buddhism - and they were all written by a single wide-eyed theosophist, W.Y. Evans-Wentz."”2 Even critics of his translations such as John M. Reynolds

1 For example, there is no mention of Evans-Wentz in Olav Hammer, Mikael Rothstein, eds., Handbook of the Theosophical Current (Leiden: Brill, 2013). For helpful comments especially in regard to Theosophy, I would like to thank Yves Mühlematter and Friedemann Rimbach-Sator. 2 John Strong, "Tensions in the Field of Religious and Buddhist Studies", in Teaching Buddhism: New Insights on Understanding and Presenting the Traditions, ed. Todd Lewis and 
acknowledge his pioneering role for the study of Nyingmapa and Kagyudpa literature. ${ }^{3}$ In this respect, extant research, most importantly by Reynolds and Donald Lopez, has for the most part been dealing with the Tibetan Book of the Dead and the idiosyncrasies of Evans-Wentz' Theosophical interpretation of Tibetan Buddhism. In addition, Evans-Wentz' biography has been studied. Actually, his life may serve as a significant example of a transcultural and transcontinental spiritual quest that led him to several countries and various encounters with remarkable figures of Asian spirituality. Still missing, though, is a work that analyzes his scholarly approach and evaluates his general contribution to the study of religion. Equally absent is a full bibliography of his contributions. Evans-Wentz' most significant books, still widely read today, were translations and studies of Tibetan Buddhism. Three of them emerged from a joint collaboration with an Indo-Tibetan scholar and translator, Lama Kazi-Dawa Samdup. His first book in this field was the ground-breaking translation The Tibetan Book of the Dead or the After-Death Experiences on the Bardo Plane, according to Lāma Kazi Dawa-Samdup's English Rendering (1927, Oxford University Press; German edition 1935). Only one year later, in 1928, Evans-Wentz published Tibet's Great Yogi Milarepa. In 1935, the study Tibetan Yoga and Secret Doctrines, or, Seven Books of Wisdom of the Great Path appeared, and finally, the last book on Tibetan Buddhism, The Tibetan Book of the Great Liberation (1954). The Tibetan tetralogy is framed by two other publications, completing the list of Evans-Wentz' book-length treatises: The Fairy-Faith in Celtic Countries (1911), and Cuchama and Sacred Mountains (1963; posthumous 1981). In addition, he published a number of articles in Theosophical and Neo-Buddhist journals, but these seemingly attracted much less attention. The relatively poor state of research on Evans-Wentz - one should note in this context that the Oxford University praised his work with an honorary degree (Doctor of Science) in Comparative Religion, ${ }^{4}$ and that Stanford University has still a "Walter Y. EvansWentz Professor" in the Department of Religious Studies ${ }^{5}$ - may nevertheless not

Gary DeAngelis (New York: Oxford University Press, 2016), ix-xi, ix-x; Conze, in "Thirty Years": "The Tantra has always been the step-child of Buddhist studies. By 1940 W. Y. EvansWentz's classical editions of Kazi Dawa-Samdu p's translations were almost the only sources of intelligible information to which the English-speaking reader could turn” (23).

3 John Myrdhin Reynolds, Self-Liberation through Seeing with Naked Awareness (Barrytown, N.Y.: Station Hill Press, 1989), 71.

4 Cf. Ken Winkler, Pilgrim of the Clear Light: The Biography of W.Y. Evans-Wentz, 2nd ed. (1982 Middletown: Booksmango, 2013), 111.

5 The "Walter Y. Evans-Wentz Professor of Oriental Philosophy, Religion, and Ethics" was created in 1983 with funds of Evans-Wentz. 
be accidental. As a matter of fact, his contributions to the emerging field of comparative religion have been fueled by strong spiritualist and esoteric motives, combined with an ardent spiritual quest that more often than not interferes with the material treated in his studies. Nevertheless, as shall be shown, his contributions had a considerable impact. Evans-Wentz was one of the first Western scholars who fully acknowledged autochthonous scholarship. He collaborated with indigenous teachers and, which was at the time not a common practice, mentioned them in his works. Moreover, his broad knowledge of Tibetan Buddhism and Yoga, but also Celtic, Christian, Gnostic, and Egyptian traditions enabled him to compare religious ideas and practices, accompanied by insights emerging from various encounters with protagonists of the respective traditions. Finally, his use of the generic concept of "books of dead" and the accompanying transcultural perspective of afterlife visions had a significant effect on the configuration of modern discourse of comparative mysticism, the analytic psychology of C.G. Jung, ${ }^{6}$ and the broadly shared assumption of a transcultural prevalence of near-death experiences. To summarize, I will try to describe Evans-Wentz's work with a special focus on his way of "doing comparative religion."

Before moving on to this aspect, I shall start with a short biography of Walter Y. Evans-Wentz. For this purpose, I will rely on the autobiography by Ken Winkler, Pilgrim of the Clear Light (1982), and I will confine myself to aspects relevant for understanding his view of religion. Evans-Wentz was born on February 2, 1878 in Trenton, New Jersey, but moved with his family to Florida and California. His father was a German, his mother of English origin. ${ }^{7}$ Winkler, Guy and Lopez hold that his parents were members of the Baptist Church; ${ }^{8}$ other sources, however, seem to suggest that he was raised as a Unitarian in the tradition of Ralph Waldo Emerson. ${ }^{9}$ But all conform that already his parents broke with organized church and favored spiritualism and freethinking. Already as a teen, he read Blavatsky's Isis Unveiled and The Secret Doctrine. Interested in spiritual experiences from early on, he was highly

6 On the relation to Jung, see William McGuire, “Jung, Evans-Wentz and various other Gurus," Journal of Analytical Psychology 48 (2003), 433-445. For C. G. Jung, the Book was of crucial importance, because to him the bardo-experiences reveal the reality of the "archetypes."

7 Winkler, Pilgrim, 19-20.

8 Cf. David Guy, "The Hermit Who Owned His Mountain: A Profile of W.Y. Evans-Wentz" Tricycle 1997, accessed August 10, 2018, https://tricycle.org/magazine/hermit-who-owned-hismountain; Donald S. Jr. Lopez, The Tibetan Book of the Dead: A Biography (Oxford \& Princeton, NJ: Princeton University Press, 2011), 22.

9 Cf. Iván Kovács, “The Tibetan Tetralogy of W. Y. Evans-Wentz: A Retrospective Assessment: Part One,” The Esoteric Quarterly, Winter 2015, 15-33; 16. 
attracted by books of "occult philosophy"10 by protagonists of the Theosophical Society, including Alfred P. Sinnett (1840-1921), whose book Esoteric Buddhism promoted not only the rebirth doctrine, but also the existence of "Mahatmas" that had somehow communicated esoteric wisdom to Sinnett. At the age of 22, he joined his father in being a successful real estate developer. Though he never left this business which offered him a considerable income, his spiritual search directed him to Loma Land, the American headquarters of the "Theosophical Society" at Point Loma, San Diego. After the death of William Q. Judge, this branch of the society had been headed by Katherine Tingley. Evans-Wentz "joined the American Section of the Theosophical Society in 1901 [. . . and] received a diploma from the Raja-Yoga School and Theosophical University in 1903." "However, he did not stay, but moved on. In 1906, he graduated from the newly-established Stanford University in English Literature. As it seems, it was William James (visiting professor at Stanford) and William Butler Yeats who raised in him further interest in spiritualist thought. He got increasingly immersed in the study of religious experience, building on "Psychical research" and the conviction of reincarnation, but also on James' idea of a pan-psychic reality permeating human existence. Evans-Wentz decided to continue research on the Celtic influences on English literature in Europe. Studying with various wellknown scholars in Oxford and Rennes, he earned a "docteur ès lettre" in 1909 from the University of Rennes with a work on Celtic folklore. In 1910, he graduated with a BSc in Anthropology from Oxford University, and published his results in 1911. After his graduation, however, he did not return to the USA, but travelled for the next six years extensively through Greece, Turkey, and stayed for three years in Egypt, studying esoteric and occult literature, but also ancient Egyptian sources, Islamic faith, or Coptic-Gnostic beliefs and practices. These studies led him to believe that early Christianity harbored still ideas of "metempsychosis." Over the years, he seemed to have developed a strong dissatisfaction with Catholicism, and followed the "Christ myth theory," that is, the belief in Christ as a deity preceded the elaboration of the "historical Jesus," if not being a "reincarnation" of a deity, which was a common belief of various Theosophists. ${ }^{12}$ In 1917, he moved on to Ceylon, meeting Adyar Theosophists such as Annie Besant, Theravāda Buddhists, and studying Indian traditions. In 1919, he visited the north of India, being now increasingly attracted to the study of Yoga practice

10 Cf. Winkler, Pilgrim, 29.

11 Lopez, The Tibetan Book of the Dead. A Biography, 22.

12 W. Y. Evans-Wentz, The Fairy-faith in Celtic Countries (London: Oxford University Press, 1911), 360. 
and philosophy. ${ }^{13}$ Most importantly, in 1919 he met Lama Kazi Dawa Samdup, an ethnically Tibetan Sikkimese, who had already served as a translator/interpreter to Alexandra David-Néel and John Woodroffe. Though Evans-Wentz and Dawa Samdup collaborated only for three years, terminated by the death of the latter (1922), Evans-Wentz could make use of Dawa Samdup's translations, publishing them in the subsequent years. As has been variously stressed, despite of EvansWentz' claim to have been a "chela," an initiated follower of his "guru” Dawa Samdup, the latter obviously did not serve as a personal Guru. ${ }^{14}$ Evans-Wentz did not receive "secret teachings" of him. As Reynolds remarks, it was almost the opposite, namely, that Evans-Wentz "occasionally attempted to foster his own views and interpretations on the Lama, as was the case, for example, with his Theosophical interpretation of reincarnation."15

As said, Evans-Wentz was not only scholarly interested, but practiced Hatha yoga (āsana-s, prānāyāma). Interestingly, he never seemed to have practiced under Tibetan Buddhist guidance, for example the six Yogas of Nāropa dealt with in his works. ${ }^{16}$ The few allusions to Buddhist practice in his autobiographical notes are somewhat metaphorical, e.g., that he practiced in solitary places "the Dharma, the Buddhist "way of truth,",17 or that he considered himself "as a faithful follower" of the "Buddha, of the Prophet, of Krishna, and of all the great Teachers" without being

13 Among his gurus were, for example, Sri Yukteswar Giri and Swami Syamananda Brahmachary; in addition, he met various important spiritual teachers such as Paramahansa Yogānanda (1893-1952), Jiddu Krishnamurti (1895-1986), Paul Brunton, Shri Ramana Maharishi, Sri Krishna Prem (i.e. Ronald H. Nixon, 1898-1965), Shunyata (i.e. Alfred J. E. Sorensen, 1890-1984), and Anagarika Govinda (i.e. Ernst L. Hoffmann, 1898-1985).

14 Cf., on their relationship, Kalzang Dorjee Bhutia, "Looking Beyond the Land of Rice: Kalimpong and Darjeeling as Modern Buddhist. Contact Zones for Sikkimese. Intellectual Communities," in Transcultural Encounters in the Himalayan Borderlands: Kalimpong as a “Contact Zone," ed. Markus Viehbeck (Heidelberg: Heidelberg University Publishing, 2017), 301-318.

15 Reynolds, Self-Liberation, 72. A prominent example for the latter can be found in EvansWentz claiming in the "Book" that the "late Lama Kazi Dawa-Samdup was of the opinion that, despite the adverse criticisms directed against H. P. Blavatsky's works, there is adequate internal evidence in them of their author's intimate acquaintance with the higher lamaistic teachings, into which she claimed to have been initiated" (Evans-Wentz, Tibetan Book, 7).

16 "Evans-Wentz did not practice under the guidance of a qualified Lama either the Six Yogas of Naropa or Māhamudrā or Dzogchen or any other Tibetan Buddhist practice for that matter. The only practice attested to in his diaries are Hindu" (Reynolds, Self-Liberation, 76).

17 Cf. Guy, The Hermit (n. p.). 
allied formally with "any of the world religions."18 He adapted an ascetic vegetarian lifestyle, visited ashrams, and joined groups of pilgrims. Actually, in his unpublished notes for an "Autobiography” (1920, cf. Winkler 2013), he described himself as a "world pilgrim" and spiritual seeker. ${ }^{19}$ In the mid-1920s, EvansWentz returned to Oxford, working intensively on the Tibetan Book of the Dead, which was published in 1927. An immediate success, he became a well-known author in the developing field of Tibetan Buddhist studies. Constantly travelling from Europe to India, the USA, and back, he earned his income by land trade and house developing. Although Evans-Wentz had bought land in order to initiate his own ashram in India (Kasar Devi, Almora), he abandoned the plan to stay there and returned to California in 1941. There he realized his final project, namely, to settle near the mountain Cuchama (at the border to Mexico), considered sacred in the American Indian tradition, and dealt with in his final monography on sacred mountains. From this final work, we may only quote here how Evans-Wentz saw his life-project retrospectively: "If there were no Otherworld, or no extra-terrestrial state of consciousness, then, indeed, there would be for man no after-death existence; and all the teachings of the Great Sages and Seers throughout the ages would be invalid. But the writer, after more than fifty years of research in the historic faiths of mankind and in matters yogic and psychic [. . .], here places on record his own conviction that there is an Otherworld." ${ }^{20}$ In 1965, he died without ever having considered founding a family to be an option.

\section{Evans-Wentz's Life-Long Occupation: Theosophy, Animism, and Re-birth}

Without doubt, it was the openness of Theosophy towards the comparative study of religion and psychic phenomena that encouraged Evans-Wentz to study Celtic myth, to search for Egyptian wisdom, and to proceed later to Yoga and Tibetan Buddhism. "Theosophical mythology singled out Egypt and later India and Tibet as the places where the perennial truths were to be found unadulterated. In particular, this was where the Masters resided."21 However, the depiction of Tibet in

18 Evans-Wentz, “Some Notes for an Autobiography”, Special Collection, Stanford University Libraries, 16.

19 Cf. Winkler, Pilgrim, 34; Evans-Wentz, "Some Notes for an Autobiography”, 3.

20 Walter Y. Evans-Wentz, Cuchama and Sacred Mountains (Ohio University Press: Athens, 1989), 82.

21 Hammer, Rothstein, Handbook, 8. 
earlier works of leading Theosophists (such as Blavatsky, or Sinnett) was highly imaginative and far from being an encounter with Tibet, or a depiction of Tibetan Buddhism - to say the least. ${ }^{22}$ In the Fairy Faith, Evans-Wentz sets out to prove that Celtic beliefs, as expressed in the living tradition, encompass an early strand of "world-wide animism," combined with the "doctrine of rebirth," as he says, and the existence of accessible otherworldly realms in this world. ${ }^{23}$ Animism, Evans-Wentz holds, "forms the background of all religions in whatever stage of culture religions exist or to which they have attained by evolution [....]; and as far back as we can go into human origins there is some corresponding belief in a fairy or spirit realm."24 Methodologically, Evans-Wentz describes himself as an "anthropologist" in the tradition of E.B. Tylor or Frazer, ${ }^{25}$ but also as applying psychology in tradition of William McDougall ("Social Psychology") and William James. ${ }^{26}$ Other terms Evans-Wentz uses for describing his method are "comparative folk-lore," 27 which opens up the perspective of comparison as such, ${ }^{28}$ and, occasionally, "comparative religion." The latter, in his understanding, allows him to trace the origin of the Celtic Otherworld belief - summing up "available facts of comparative religion, philosophy, and myth" - to "a prehistoric epoch when there was a common ancestral stock for the Mediterranean and pan-Celtic cultures." ${ }^{29}$ In addition

22 Cf. Olav Hammer, Claiming Knowledge: Strategies of Epistemology from Theosophy to the New Age (Leiden: Brill, 2004), 133-134.

23 Cf. Winkler, Pilgrim, 44-48.

24 Evans-Wentz, Fairy-Faith, 227.

25 Cf. on Tylor's evolutionary theory, Evans-Wentz, Tibetan Book, 59-60; on the relationship to Tylor, see Bryan J. Cuevas, The Hidden History of the Tibetan Book of the Dead (Oxford and New York: Oxford University Press, 2003), 218.

26 Cf. Evans-Wentz, Fairy-Faith, xii, 282, 484, 505.

27 Here, the dominant influence of Sir John Rhys (1840-1915), Andrew Lang (1844-1912) and George William Russell (the "Irish mystic") (1867-1935) can be felt, as outlined by Friedemann Rimbach-Sator, “'Esoteric Fairy Faith.' The Theosophical Background of Walter Y. EvansWentz's The Fairy Faith in Celtic Countries” (master's thesis, University of Amsterdam, 2018), 6, 22.

28 Evans-Wentz, Fairy-Faith, 281, holds that "comparative folk-lore" shows that in regard to the Fairy-Faith and its elements - relating to the "smallness of fairies, to changelings, to witchcraft and magic, to exorcisms, to taboos, and to food-sacrifice," "the beliefs composing it find their parallels the world over, [. . .] not only in Celtic countries, but in Central Australia, throughout Polynesia, in Africa, among American Red Men, in Asia generally, in Southern, Western, and Northern Europe, and, in fact, wherever civilized and primitive men hold religious beliefs."

29 Evans-Wentz, Fairy-Faith, 396. 
to the basis of religion in "animism," he is convinced that a "re-birth doctrine" is expressed in various early traditions such as in certain Alexandrian Christians, Gnostic sects, and Indian traditions. ${ }^{30}$ Most significant, in this respect, are the chapters VII on "The Celtic Doctrine of Re-Birth," and the concluding chapter XII, "The Celtic Doctrine of Re-Birth and Otherworld Scientifically Examined." ${ }^{31}$ As evidence for Celtic re-birth doctrines, he adduces, for example, the "changeling creed," "soul-abductions," etc., being evidence to "a greatly corrupted folk-memory of an ancient re-birth doctrine: the living are taken to the dead or the fairies and then sent back again." 32 In broad strokes, he compares Celtic myths with initiation rites of Egyptian mystery cults, exhibiting a belief of "spiritual resurrection" and "re-birth into real life."33 Most central for his views is the definition of "death," which "is but a going to that Otherworld from this world, and Birth a coming back again, and Buddha announced it as his mission to teach men the way to be delivered out of this eternal cycle of existence." 34 The concept of "re-birth," in other words, is closely linked to the Theosophical idea of a "felicitous" rebirth into human life, and enabled by this, the possibility lays open to progress into a divine being that will enjoy its otherworldly existence after-death - a general idea that Evans-Wentz sees in Celtic faith and, already in view, the "Nirvana of Buddhism." 35 Other ideas that I shall only mention in passing are his conviction that the Celtic doctrine of re-birth attests that there is a spiritual (or "vitalistic") evolution in the human domain towards perfection (and which includes "Darwinism" as only its lowest form). ${ }^{36}$ This evolution is now scientifically corroborated in Psychical Research of

30 Evans-Wentz, Fairy-Faith, 362.

31 Evans-Wentz refers to Alfred Nutt's Happy Otherworld and the Celtic Doctrine of Re-birth (1897), in which the general thesis of a scientific "comparative mythology" proving the doctrine to be common among Celts, Greeks, and Hindus had already been established (cf. EvansWentz, Fairy-Faith, 358).

32 Evans-Wentz, Fairy-Faith, 252. Other evidence pertains to Celtic "heroes" such as "Cuchulainn and Arthur," who were, in his view, "considered reincarnate sun-divinities," so that, "as a sungod, Arthur is like Osiris, the Great Being, who [. . . ] enters daily the underworld or Hades to battle against the demons and forces of evil, even as Tuatha De Danann battled against the Fomors" (Evans-Wentz, Fairy-Faith, 310; cf., on Osiris, 321).

33 Evans-Wentz, Fairy-Faith, 313.

34 Evans-Wentz, Fairy-Faith, 358-359.

35 "It seems clear that the circle of Gwynvyd finds its parallel in the Nirvana of Buddhism, being, like it, a state of absolute knowledge and felicity in which man becomes a divine being, a veritable god” (Evans-Wentz, Fairy-Faith, 366).

36 "Scientifically speaking," Evans-Wentz holds, "the ancient Celtic Doctrine of Re-birth represented for the priestly and bardic initiates an exposition of the complete cycle of human evolution," that is "Darwinism," and, in addition, a theory of "man's own evolution as a spiritual 
spiritualist phenomena. ${ }^{37}$ To substantiate this claim, Evans-Wentz discusses in the concluding chapter extensively F. Myers' "subliminal self," 38 or W. James' "subconscious self." 39 It should be worth noting that both, Myers and James, were early members of the Society for Psychical Research (SPR), founded in 1882. In this line, he believes in the pre- and post-existence of an "indestructible" soul, or personal consciousness declared to be an emanation of a larger consciousness filtered into the individual brain. Expressing rather common convictions of Spiritualists and certain psychologists of the late $19^{\text {th }}$ century, he draws on the metaphor of a "reservoir" of consciousness (as used by F. Myers, George Mead, among others): "We may regard this psychical power as like a vast reservoir of consciousness ever trying to force itself through matter." 40 The imagery finally ends in a spiritualist utopia that the vast reservoir will overflow its banks and transform the fully evolved man into the "subconsciousness." 41 In the concluding chapter, Evans-Wentz aims to offer a "scientific explanation" of the validity of Celtic rebirth beliefs. However, this explanation consists merely in stating that modern psychical research has been able to demonstrate "support" for the existence of "veridical hallucinations," supernatural "noises," visions, dreams, trance states, and "spirit-possession." In this vein, he adduces evidence of psychology that attests the existence of a "supernatural' lapse of time" ${ }^{22}$ or that states of consciousness exist without any relation to the individual. However, these assumptions of a trans-individual nature of (reincarnating) consciousness often rather vaguely refer to an "x-quantity" that indicates the "noumenal world" of consciousness, and spirits as higher "explanation" for things that happen in the phenomenal world. ${ }^{43}$

being both apart from and in a physical body, on his road to the perfection which comes from knowing completely the earth-plane of existence" (Evans-Wentz, Fairy-Faith, 365).

37 For Evans-Wentz, it is "self-evident" that the "Celtic Doctrine of Re-birth" is a "direct and complete confirmation of the Psychological Theory of the nature and origin of the belief in fairies," and there is "much evidence to be derived from a study of states of consciousness, e. g. dreams, somnambulism, trance, crystal-gazing, changed personality, subconsciousness" (EvansWentz, Fairy-Faith, 383).

38 Evans-Wentz, Fairy-Faith, 465-490. The "subliminal self" is still a category of his later works, cf., e.g., Evans-Wentz, The Tibetan Book, 31, 97; Evans-Wentz, Tibetan Yoga, 5.

39 Evans-Wentz, Fairy-Faith, 506.

40 Evans-Wentz, Fairy-Faith, 498, cf. 501.

41 Cf. Evans-Wentz, Fairy-Faith, 498.

42 Cf. Evans-Wentz, Fairy-Faith, 459-471; especially the cases of the "life review" in the drowning are noteworthy here, cf. Jens Schlieter, What is it like to be Dead: Near-death Experiences, Christianity, and the Occult (New York: Oxford University Press 2018), 160.

43 Cf. Evans-Wentz, Fairy-Faith, 490-493. 
In sum, the method and theory that governs Fairy-Faith joins psychical research of the time in assuming that a theoretical explanation may simply consist of a metaphysical theory of the pre- and post-existence of "consciousness," which is attested by religious discourse, a vitalistic interpretation of Darwinism, and latest experimentation with paranormal phenomena. In contrast to Theosophical doctrines that reign, as Rimbach-Sator has shown, almost all of the book's background assumptions, ${ }^{44}$ Psychical Research is far more prominently quoted. Only few passages openly express the necessity to use Theosophical terminology (e.g., the "astral body," or the "astral plane"45), disguising on the surface Evans-Wentz 's use of an elaborate Theosophical framework, whose specific position within Theosophy more broadly shall not discussed here. Methodologically, however, Evans-Wentz does not reflect explicitly on how a comparison of different religious traditions, of their ideas, or of concepts should be done. Instead, he directly identifies spiritual teachers of various traditions as advanced beings destined to teach the world. Obviously intrigued by the Theosophical idea that "comparative folk-lore" as such will show the ubiquity of otherworld narratives, he outlines a reincarnation process that will include a happy destiny in the beyond, and finally, perfection. The truth of Fairy tales, he holds, will in the not too distant future be proven by (Psychical) science.

\section{Evans-Wentz' Tibetan Tetralogy}

Without question, Evans-Wentz publication of the Tibetan Book of the Dead in 1927, given his broad reception and overwhelming success (more than 500'000 copies sold in English alone), was his most outstanding achievement. Its effect and impact on the Western view of Tibetan Buddhism in general, and of "transcultural" after-death experiences in particular, were tremendous. In regard to the accuracy of Evans-Wentz's depiction of Tibetan Buddhism, however, we can only restate what Donald Lopez observed, namely, that for the modern

44 Rimbach-Sator, Esoteric Fairy Faith, 41, is able to show Theosophy present at the very basis of Evans-Wentz's interpretation: "Concerning the lower fairies, the esoteric fairy faith reflects the Theosophical debate on elementals that appear in séances and dwell in the same realm of the recently departed: Kama Loca. This purgatory realm is the subjective pre-state of the positive dwelling of the immortal Monad until reincarnation: Devachan. This reveals fairyland as the Theosophical afterlife state Kama Loca / Devachan" - in short: "Theosophical theory in a Celtic light."

45 Cf. Evans-Wentz, Fairy-Faith, 29, 167-171. 
scholar of Tibetan Buddhism Evans-Wentz's books are "fraught with problems: errors in translation, inaccurate dates, misattributions of authorship, misstatements of fact, unjustified flights of interpretation." ${ }^{46}$ Relying on the essential translation work of Dawa Samdup - Evans-Wentz never learnt Tibetan - he compiled various "treasure" texts that belong to a class of secret Tantra teachings on how to behave in the after-death state (bar do). These texts were in Tibet designated as bar do thos grol, "Liberation through hearing in the Intermediate State." In its first edition, the Book contained a "Preface" by EvansWentz and a foreword "Science of Death" by Sir John Woodroffe. The third edition of 1957 added a "Psychological Commentary" by C. G. Jung, that had been prepared for the German edition (1935), and an "Introductory Foreword" by Lama Anagarika Govinda.

I will only shortly summarize the teachings of the Book as portrayed by Evans-Wentz in 1927. For this purpose, it is not necessary to discuss in detail if the translation is appropriate judged by present day knowledge of Tibetan Buddhist teachings. Although the Tibetan historical and ritual context of these teachings was mentioned by Evans-Wentz, it was put in the background in favor of presenting the Book as "scientific, psychological, and humanistic." " Evans-Wentz holds it to be scientific, based on a transcultural dimension of "Symbol-codes" which can also be found, for example, in the "Egyptian Book of the Dead," Christian ars moriendi, or Greek mythology. These "symbol-codes" now prepare the ground for an esoteric-occult reading of otherworldly journeys. Obviously, Evans-Wentz could easily adapt the title "Book of the Dead," a title that was well established for the Egyptian context. ${ }^{48}$ "As a mystic manual for guidance through the Otherworld of many illusions and realms, whose frontiers are death and birth, it resembles The Egyptian Book of the Dead sufficiently to suggest some ultimate cultural relationship between the two," he says. ${ }^{49}$ Evans-Wentz holds that the Book is an outstanding example for the "Art of Dying," aiming to teach the dying to be clear-minded and calm when death approaches. The Tibetan art of dying encompasses, he explains, alluding to Theosophical imagery, the art "of

46 Donald Lopez, "Foreword to Evans-Wentz," The Tibetan Book, G.

47 Michael Nahm, "The Tibetan Book of the Dead: Its History and Controversial Aspects of Its Contents." Journal of Near-Death Studies 2011, 29 (3): 373-398, 375.

48 In 1842, it had been introduced by Prussian Egyptologist Karl R. Lepsius in his Das Todtenbuch der Ägypter ("Egyptian Book of the Dead"). It took only some years before becoming in all European languages the common designation for the whole genre of Egyptian hieroglyphic funerary texts portraying the deceased's journey to the underworld (cf. Lopez, Biography, 101). Egyptian afterlife conceptions were highly important to Western occultism and Esotericism, e.g., for H. P. Blavatsky.

49 Evans-Wentz, The Tibetan Book, 2. 
going out from the body, or of transferring the consciousness from the earthplane to the after-death plane" is, he adds, known as Pho-wa and still practiced in Tibet. ${ }^{50}$ In his first introduction to the teachings of the Book, Evans-Wentz describes it as a "mystic manual for guidance through the Otherword," 51 and holds that spiritually advanced encounter death with "solemn joyousness." 52 It presupposes an accompanying 'spiritual friend' reading passages aloud to the dying, or, more precisely, to the deceased consciousness that is imagined to be still around - outside of his former body. This manual, he says, describes how the "principle of consciousness" of the deceased enters a "trance-state" at the moment of death. This is the first after-death state of three "intermediate states" (Tibetan bar do), which amount to a maximum of 49 days until the "consciousness" turns to its next existence. The first bardo is the "Transitional State of the Moment of Death', wherein dawns the Clear Light.” For the one who is not able to stay focused on the "Clear Light" (Tib. 'od gsal), the second bar-do emerges, the "Transitional state [. . .] of Reality" (Tib. chos nyid bar do). Here, negative karma, heaped up through evil acts committed in lifetime, will produce "hallucinations": "thought-forms, having been consciously visualized and allowed to take root and grow and blossom and produce, now pass in a solemn and mighty panorama." 53 Now the deceased, becoming aware of his death, develops a desire to possess a body again. Finally, if the wandering consciousness fails to recognize reality in the second bardo, the third, the "bardo of mundane existence," will dawn, which comprises lively visions of punishment and judgment. It ends with the search for a new body. The narrator, advising the disembodied consciousness, serves, as Evans-Wentz observes, as a "guide for initiates." 54 With this comment he aims to underscore the structural similarity of the Tibetan "guide" with those described in early Mediterranean milieus of esoteric mystery cults. For Evans-Wentz, as he discloses in 1959, these claims are based on insights grounded on the "unequivocal testimony of yogins who claim to have died and re-entered the human womb consciously" - they are therefore "truly scientific and yogic." 55 Given the description of "scientific Re-birth theory" in the "Fairy-Faith," this view does not astonish.

50 Evans-Wentz, Tibetan Book, xiv, referencing his own work, namely Tibetan Yoga and Secret Doctrines (London: Oxford University Press, 1935), 169-170, 246-276.

51 Evans-Wentz, Tibetan Book, 2.

52 Evans-Wentz, Tibetan Book, xvii.

53 Evans-Wentz, Tibetan Book, 29.

54 Evans-Wentz, Tibetan Book, lxi.

55 Cf. Evans-Wentz, Tibetan Book, v. 
As said above, the Book vitalized visionary imaginings of "out of body experiences," which can be easily connected to Theosophical intentional practices of "astral projection," or, as quoted above, to the "art of going out of the body." 56 A somewhat astonishing fact is Evans-Wentz' choice of a King-James-Bible-style translation language. In Wentz and Samdup's translation, we read: "When the consciousness-principle getteth outside [the body, it sayeth to itself], 'Am I dead, or am I not dead?' It cannot determine. It seeth its relatives and connexions as it had been used to seeing them before. It even heareth the wailings." 57

As an example of Evans-Wentz' method and guiding assumptions we may turn to the "judgment scene" found in the Book. Evans-Wentz, arguing for a close relation to ideas expressed in the Egyptian Book of the Dead, indulges once more in historical speculations on a common origin of Tibetan Buddhist, Egyptian, Greek, and, finally, Christian judgment scenes. ${ }^{58}$ The greater part of Christian "symbolism" is for Evans-Wentz an adaptation of Egyptian and Eastern religions. He still adheres to an inner core beyond cultural particularities. It comes as no surprise that he can present a "Buddhist" reading of the Platonic myth of Er, discovering "karmic record boards" 59 there, or that he identifies a symbolic common core in the "weighing" of the soul. This outlook that glosses over specific contexts shares, methodologically, convictions of cross-cultural interpretation of the "phenomenology of religion," for example, by Mircea Eliade. More specifically, Evans-Wentz rests on the belief that the doctrine of rebirth is an essential pre-Christian doctrine that remains visible in some medieval Christian teachings on the art of dying. ${ }^{60}$ For Evans-Wentz, the Book could, however, add an important and decisive moment with its "psychological" theory that not only describes a commonality, but adapts the

56 Cf. Evans-Wentz, Tibetan Book, xxxiii; 92, 100. He equates the Tibetan Tantric Buddhist concept of an "illusory body" (Tib. sgyu lus) with the "astral-body" of Theosophy.

57 Evans-Wentz, Tibetan Book, 98.

58 "Judgment Scenes," Evans-Wentz (Tibetan Book, 35) argues, are so similar "in essentials" that a common origin, "at present unknown," seems certain. And he continues: "In the Tibetan version, Dharma-Raja (Tib. Shinje-chho-gyal) King of the Dead [. . .], the Buddhist and Hindu Pluto, as a Judge of the Dead, corresponds to Osiris in the Egyptian version. In both versions alike there is the symbolical weighing."

59 Plato, he says (Tibetan Book, 36), describes in the myth of Er (Republic, 10 ${ }^{\text {th }}$ book) a similar judgment, in which "there are judges and karmic record-boards (affixed to the souls judged) and paths - one for the good, leading to Heaven, one for the evil, leading to Hell - and demons waiting to take the condemned souls to the place of punishment, quite as in the Bardo Thodol."

60 Cf. Evans-Wentz, Tibetan Book, 239-240. 
teaching itself as an element of his own understanding on how religious plurality should be explained. Evans-Wentz speaks of "hallucinatory visions" in the second bardo, and uses term, "hallucinations," in his translation of the Tibetan text. ${ }^{61}$ These "hallucinations" are triggered by karmic forces and are therefore dependent on the individual's conscious life. The Book, consequently, "views the problem of the after-death state as being purely a psycho-physical problem; and is, therefore, in the main, scientific. It asserts repeatedly that what the percipient on the Bardo plane sees is due entirely to his own mental-content; that there are no visions of gods or of demons, of heavens or of hells, other than those born of the hallucinatory karmic thought-forms constituting his personality." ${ }^{2}$ Actually, in the Fairy-Faith he already introduced the "panoramic life review"-feature, reported by individuals of death-threatening situations such as drowning, as a perfect, "scientifically valid" device to explain paranormal memories in close-to-death (and after-death-) states. He could now argue that these extraordinary visions of one's whole life condensed in seconds are nothing less but each "seed of thought" that "karmically revives."63 Building on this adaptation of the interpretation of hallucinatory effects of karma, EvansWentz is able to declare that, accordingly“ for a Hindu, or a Moslem, or a Christian, the Bardo experiences would be appropriately different: the Buddhist's or the Hindu's thought-forms, as in a dream state, would give rise to corresponding visions of the deities of the Buddhist or Hindu pantheon; a Moslem's, to visions of the Moslem Paradise; a Christian's, to visions of the Christian Heaven, or an American Indian's to visions of the Happy Hunting Ground.” In conclusion, "this psychology scientifically explains why devout Christians, for example, have had [. . .] visions (in a trance or dream state, or in the after-death state) of God the Father seated on a throne in the New Jerusalem, and of the Son at His side, [. . .], or of Purgatory and Hell." 64

Evans-Wentz, however, declares his own contribution to be comments of Tibetan doctrines from a comparative religion point of view, while, at the same time, he transgresses pure comparisons by identifying the comparanda. In an appendix, he once again voices his "hypothetical" opinion that there is a common core in the religious traditions - for example, in Christian monasticism and its "yoga-like practices" that he believes to have a "direct relationship with the more ancient monastic systems such as those of Hinduism, Buddhism, Jainism, and Taoism," or (as already proposed in his Fairy Faith), that "esoteric Christianity"

61 Cf. Evans-Wentz, Tibetan Book, 156, 167.

62 Evans-Wentz, Tibetan Book, 34.

63 Evans-Wentz, Tibetan Book, 33.

64 Evans-Wentz, Tibetan Book, 34. 
was "in general accord with the old Oriental teachings touching Rebirth and Karma." ${ }^{65}$ But neither a theory of direct historical dependency, nor the Theosophical theory of how such strikingly parallel development come about, is offered. Instead, Evans-Wentz alludes to the possibility that - in the same way as the Buddha merely restated what already prehistoric Buddhas had found - the Christian doctrine may build on pre-Christian doctrines, which once more reckons with a common esoteric core. However, in the later Christian development, these esoteric teachings had been transformed into Church-based exoteric teachings of an anthropomorphic deity, the singularity of Jesus, faith in a Savior, forgiveness of sins, and of a condemnation of rebirth-beliefs or spiritual evolution, etc. In regard to the latter, the spiritual evolution in higher realms, an evolutionary process that precludes rebirth in lower realms, e.g., humans as animals, Evans-Wentz' intentional isogetic reading of Tibetan Buddhism (and their non-evolutionary understanding of karma and rebirth) is obvious. ${ }^{66}$

In what reminds us of Max Müller's pathetic self-perception of the value of "comparative religion," Evans-Wentz argues that "the hope of all sincere researchers into comparative religion devoid of any religious bias ought always to be to accumulate such scientific data as will some day enable future generations of mankind to discover Truth itself - that Universal Truth in which all religions and all sects of all religions may ultimately recognize the Essence of Religion and the Catholicity of Faith." 67 The essential categories that Evans-Wentz applies in these contexts are the "thought-forms" of Theosophy, declared to be the ground layer visible in religious "symbolism" 68 - for example, the Christian "weighing" of souls

65 Evans-Wentz, Tibetan Book, 234.

66 Evans-Wentz (Tibetan Book, 42-43) holds, in line with prominent Theosophists, that the exoteric interpretation of karma may entail the human "life-flux" "very often does take reembodiment in sub-human creatures," but in its "esoteric interpretation," according to "various philosophers, both Hindu and Buddhist, from whom the editor has received instruction," the "human life-flux to flow into the physical form of a dog, or fowl, or insect, or worm, is [. . .] held to be as impossible."

67 Evans-Wentz, Tibetan Book, 1.

68 Evans-Wentz offers no reference, but probably refers to "Thought-Forms" in their earlier meaning as, for example, outlined by Sinnett. In the A.P. Sinnett, The Occult World, 2nd Am. Ed. (Boston: Houghton, Mifflin, and Co., 1885), 129, we read: "The human brain is an exhaustless generator of the most refined quality of cosmic force out of the low, brute energy of Nature [. . .]. This is the key to the mystery of his being able to project into and materialize in the visible world the forms that his imagination has constructed out of inert cosmic matter in the invisible world. The adept does not create anything new, but only utilizes and manipulates materials which Nature has in store around him, and material which, throughout eternities, has passed through all the forms. He has but to choose the one he wants, and recall it into objective existence." 
in the "bar-do," as he says - that finally prove to be "adaptations from Egyptian and Eastern religions." 69 Already in his introduction to the book, he refers to these as "symbol-codes": Although the book treats the doctrine of "rebirth" as a scientifically given fact, it occasionally departs from the "rational." This, EvansWentz holds, is only a superficial reading, as it is merely the outcome of "a secret international symbol-code in common use among the initiates."70 This, of course, corresponds well, he says, with Western Occultist ideas of a "hidden symbolism" engrained in secret language. The hidden pagan dimensions in Christianity have been condemned by "uninitiated ecclesiastics," as “'Oriental imagery gone mad." "71 While he admits that those esoteric ideas of a hidden symbolism hold especially true for "Northern Buddhism" with its claim to possess an orally transmitted, secret (Yogic) teaching of the Buddha not in line with a literal reading of the "Southern" Pali Canon, even the parables and metaphors of the latter can be read "symbolical."72 In short, “"Esoteric Buddhism,' as it has come to be called rightly or wrongly - seems to depend in large measure upon 'ear-whispered' doctrines of this character, conveyed according to long-established and inviolable rule, from guru to shișhya [sic], by word of mouth alone."73

This hermeneutic principle of hidden meanings and symbolic codes allows not only to adhere to a common esoteric core. It empowers Evans-Wentz to harmonize his reading with earlier canonical Theosophist teachings of having been "communicated" by Mahatmas of Tibet (Sinnett), or with what Helena Blavatsky had described as "her decoding of The Stanzas of Dzyan in the secret Senzar language."74 In his only remark on Blavatsky in the Book, he defends her with an allegedly positive comment by Dawa Samdup on her intimate knowledge of "higher lāmaistic teachings." 75 Although Evans-Wentz does not refer to Alfred P. Sinnett's Esoteric Buddhism in the Book, ${ }^{76}$ there are clear similarities in their understanding of the secret knowledge of "esoteric Buddhism." In his work of 1885, Sinnett had offered a neo-Hinduist reading of the Buddha. A "secret knowledge, in reality, long antedated the passage through earth-life

69 Evans-Wentz, Tibetan Book, 241.

70 Evans-Wentz, Tibetan Book, 3.

71 Evans-Wentz, Tibetan Book, 4.

72 Evans-Wentz, Tibetan Book, 5.

73 Evans-Wentz, Tibetan Book, 5.

74 Donald Lopez, Afterword to the Tibetan Book, 253.

75 Evans-Wentz, Tibetan Book, 7.

76 He mentions, however, the impact Sinnett's works Esoteric Buddhism and Occult World had on him in his "Notes for an Autobiography", 18. 
of Gautama Buddha. Brahminical philosophy, in ages before Buddha, embodied the identical doctrine which may now be described as Esoteric Buddhism," and "Shankaracarya" being the newly reincarnated Gautama Buddha. ${ }^{77}$ In the same vein, Evans-Wentz declares that, despite some doctrinal differences, the "state of liberation" as conceptualized by Samkara, is essentially the same as the "Buddhist void."78 In other words, Evans-Wentz, in line with hidden "symbol codes," saw no need to correct earlier Theosophical doctrines (and never criticizes classical Theosophical depictions of "Tibetan teachings") but could express his interpretation in this established framework.

To summarize, we can see how the Tibetan Book of the Dead was especially acknowledged for validating claims of "astral projection" and the transmigrating soul on a transcultural basis. In its special Theosophical reading, based on a translation already inspired by Theosophy, it offered new evidence for the common core of esoteric teachings of early traditions in general, and the "scientific proof" of rebirth with the soul's near- and after-death experiences in particular. Moreover, the insights provided were taken as psychological, scientific, and experiential evidence of a "non-duality" that interpenetrates and correlates both the disembodied mind and its "experienced" environments. Gods, after-death planes of existence, etc., are neither an objective reality nor merely psychological artifacts, but do exist on a conventional level if somebody experiences them. This idea could now be used to accredit the cultural variability of heavens, hells, God, or the quality of light (or "the Light”) experienced, without, however, relativizing the "experiences" themselves. Championing Theosophy, Evans-Wentz could implicitly argue that the Book was a perfect basis to evaluate the wisdom of the "Tibetan Masters," mediumistically received by the first generation of Theosophists, despite all disputes in respect to the formers' existence, or the latter's veracity, respectively.

In 1928, Evans-Wentz published a second book on Tibetan Buddhism, this time consisting mainly in a translation of the life-story of Milarepa, a Tibetan Buddhist mystic, poet, and Tantrist practitioner of the $11^{\text {th }}$ century and one of the founding figures of the Kagyu-school, written in the $15^{\text {th }}$ century by Tsangnyön

77 Sinnett, Esoteric Buddhism, 3, cf. 147-150, argues: "Buddha reincarnated himself, nest after his existence as Gautama Buddha, in the person of the great teacher of whom but little is said in exoteric works of Buddhism, but without a consideration of whose life it would be impossible to get a correct conception of the position in the Eastern world of esoteric science namely, Sankaracharya," reappearing in order to "repair certain errors in his own earlier teachings" - i.e., the problems caused by the Buddha passing esoteric knowledge into inferior castes.

78 Evans-Wentz, Tibetan Book, lxxiii. 
Heruka. Despite the greater fame of his first book, the book on Milarepa was his most influential in academia, used in emergent Tibetan Buddhist Studies for decades. In the introduction to the work, mainly consisting in an outline of the Tibetan context, we find only occasional allusions to Theosophy, and his comparative remarks - for example, on parallels between Gnosticism and Tibetan Buddhism of the "Kargyütpas," are for the most part very general in nature. The main focus is, again, on the common ancient rebirth doctrine, the search for "realization" and salvation - in Gnostic tradition, the "Enlightenment of Christhood"79 - and the nature of ultimate reality: "The Un-Created, Non-Being, or Body of All-Intelligence, the Impersonal Deity of Christian Gnosticism, may be compared with the Voidness of the Mahāyānic Schools." 80 In a section on "The defense of the hermit ideal," Evans-Wentz, obviously describing his personal vision, ${ }^{81}$ draws freely from early Buddhism, Mahāyāna, and Neo-Hinduist thought, and does not spare the reader to read of his criticism of modern life of Wall street financiers or pleasure-seekers. In all societies, we, learn, yogins emerge who look - with empathy - on their contemporaries as trapped in a net of deceptive karmic illusions. These yogins are not only true "guardians" for their peers. As "scientists" of spiritual cultivation, they serve as essential agents in the ongoing spiritual evolution of humanity; ${ }^{82}$ their ideal being an "unselfish preparation for service to the Race." 83 As Milarepa's life bears witness, however, the Yogin (as a comparative category applied to Indian traditions, but also to Sufism, Taoism, and Gnostic Christianity) must first realize his insights in solitude, which will allow him to return as a "World-Teacher" to human society. These descriptions prepare the ground for the final argument of the introduction in which one can surely see an attempt to justify the classical Theosophical claim to have been in contact with hidden "Mahatmas" and their supernatural capacities. Evans-Wentz argues that such "Arhants," being in passion of powers "as yet undiscovered, but probably suspected, by Western Science,"84 still exist today, though only “exceedingly few.”

79 W. Y. Evans-Wentz, Tibet’s Great Yoḡ Milarepa (London: Oxford University Press, 1928), 11.

80 Evans-Wentz, Milarepa, 11.

81 Cf. Evans-Wentz, Milarepa, 18.

82 Evans-Wentz, Milarepa, 17: "It must equally be kept in mind, in judging the yogi, that he claims to have proved, at least to himself, by methods as careful and scientific in their own realm as those known in the laboratories of the West in the realm of physical science, that the ideals of the worldly are merely the ideals of an immature social order, of races still in the lower and middle grades of the World-School."

83 Evans-Wentz, Milarepa, 18.

84 Evans-Wentz, Milarepa, 20. 
However, for Evans-Wentz, "the only valid and scientific procedure is to explore for oneself the path leading to Arhantship, as Milarepa herein bids us do." 85 The only precondition for the Western sceptic would be an open attitude as being the case of scientific experimenters: "Without faith that a certain experiment may lead to a certain result, no chemist or physicist could possibly discover fresh scientific truths; and no man can ever expect to discover that New World, of which Milarepa sings in his ecstatic joy of triumph, unless he first sets up a postulate that there is a New World awaiting his discovery." 86 Actually, the analogy to experimentation in natural sciences does only partly suffice: For Evans-Wentz, the outcome of the experiment is already known - a problem that he solves by leaving the analogy of experimentation for the more plausible imagery of discovering a new territory, a "New World." In sum, in this work, the scholar-practitioner Evans-Wentz appears only alludes to the deeper layers of the common spiritual heritage, while a discussion of his claims, and remarks on methodology of comparative religion are fully absent.

In 1935, Tibetan Yoga and Secret Doctrines saw the light. In addition to its translations of seven Mahāyāna Buddhist texts, which will not be dealt with here, it contains a lengthy introduction that once more testifies the biographical stability of Evans-Wentz's beliefs. In his attempt to subsume the Indian and Tibetan doctrines of the seven texts under the heading of "Yoga," the style of his explanations changes, coming closer to Guru-like attitudes visible in NeoHinduist and Neo-Vedāntist Indian contemporaries of Evens-Wentz. But not only that: With "Yoga" as the unifying principle of the mastery of breath, will, energy, knowledge, and the self, Evans-Wentz seems to have no problem to explain Buddhist Yoga with explanations and descriptions drawn from classical Hindu texts and Neo-Vedāntist, probably oral, teachings. Yoga, in consequence of being refined to a transcultural category, is everywhere: "the applied psychology of religion, yoga is the very tap-root of Hinduism, Buddhism, Jainism, and Taoism. Similarly, if perhaps in less degree, it has nourished the growth of the Faith of the Parsees; and in the development of the three Semitic Faiths, Judaism, Christianity, and Islam, it has been a very important shaping influence." 87 And, of course, "initiation into the Mysteries of Antiquity was largely yogic," $" 88$ as were the practices by Christian ascetics and monastics, Egyptians, Greeks, Romans, or the Celtic druids. Grounded in the nature of reality itself, it seems so obvious for Evans-Wentz that he makes no effort to substantiate his

85 Evans-Wentz, Milarepa, 24.

86 Evans-Wentz, Milarepa, 24.

87 Evans-Wentz, Tibetan Yoga, 35.

88 Evans-Wentz, Tibetan Yoga, 35. 
claims with remarks on historical dependencies, or with a close comparative reading of respective texts. For Evans-Wentz, there is not even a need for this. If the category of "Yoga" can be applied to Occidental traditions, "Yoga," correctly understood, is as much a Western tradition as it is Eastern. As in earlier works, comments on methodology are absent, and very few passages try to systematize the material presented. Evans-Wentz describes himself as being an "anthropologist" of internal universe, driven by an? interest in "anthropology and psychology as applied sciences in the sense understood in yoga." 89 Still, Theosophy is underlying framework, obvious in Evans-Wentz depiction of "occult fraternities of India and Tibet," that may convey their insights "telepathic," in symbols, or oral, but "never completely by means of written records." 90

In 1954 the concluding volume of the Tibetan tetralogy appeared: The Tibetan Book of the Great Liberation, containing excerpts of texts on Padmasambhava, the mythical founder of Tantrism in Tibet, and on Dzogchen, "the great perfection," a Tibetan system of Tantric teachings, and an introduction. While there is a considerable overlap with his earlier Theosophist, Neo-Vedāntist, and Neo-Platonic reading of Tibetan Buddhism - the focus now being on the "one mind," or "atone-ment" - it is the tone that has changed. In his introduction, Evans-Wentz declares with pathos that the "Yoga of Knowing the Mind in its Nakedness," translated in the work, is known as "the doctrine which automatically liberates man from bondage [. . . ]. In common with all schools of Oriental Occult Sciences, the Mahāyāna postulates that the One Supra-Mundane Mind, of Universal AllPervading Consciousness, transcendent over appearances and over every dualistic concept born of the finite or mundane aspect of mind, alone is real. Viewed as Voidness, it is the Become, the Unborn, [. . .] the predicateless Primordial Essence, the abstract Cosmic Source where all concrete or manifested things come and into which they vanish into latency." This "One Mind" is "the Transcendent Fullness of the Emptiness, the Dissolver of Space and Time and of sangsāric (or mundane) mind, the Brahman of the Rishis, the Dreamer of Māya , the Weaver of the Web of Appearances, the Outbreather and the Inbreather of infinite universes throughout the endlessness of Duration." 91 However, the Tibetan text does mention the "one mind" only once and does not build, as Reynolds remarks, on the view of "some sort of Neo-Platonic hypostasis, a universal Nous, of which all individual minds are but fragments or appendages." 92 To Evans-Wentz, it is the "One

89 Evans-Wentz, Tibetan Yoga, 48.

90 Evans-Wentz, Tibetan Yoga, 50.

91 Evans-Wentz, The Tibetan Book of the Great Liberation, 1.

92 Cf. Reynolds, Self-Liberation, 80: "However, there is no equivalent in the actual Tibetan text for his "the One Mind.” The phrase sems gcig-po occurs in one place where it means "It is 
Cosmic Mind," "the unlimited Supra-Mundane Mind,"93 formed of "mankind's minds, or consciousnesses," that "are collectively one," forming in their entirety the "body of one great multi-celled organism, mentally illuminated by the One Cosmic Mind," and being the unknown source of "cosmic rays and matter in all its electronic [sic] aspects, as light, heat, magnetism, electricity, radio-activity," etc. ${ }^{94}$ The vision that Evans-Wentz follows here is that the individual consciousness will merge with the cosmic one if evolved enough, and that exactly this is meant in the Buddhist nirvāna. A new, overly enthusiastic tone may be seen not only as mirroring Indian Neo-Vedānta, but as also anticipating psychedelic mysticism of the 1960s, if not the writings of NewAge authors of the 1980s. Moreover, the whole concept, in line with the Spiritualist's bursting reservoir of consciousness mentioned above, shares certain traits of Aldous Huxley's "mind at large" - probably not accidentally, Huxley's work The Doors of Perception, expanding the idea, was published in the same year, 1954.

Generally, it must be said, Evans-Wentz misses to acknowledge the advanced epistemology of Buddhism. Any critical reflection on the limitation of language, prominent in Madhyamaka and Yogācāra philosophers, is absent. As has been the case in his earlier works, there are few suggestions of a systematization - for example, that the "Orient" developed four methods of imparting spiritual knowledge beyond "literacy," namely, through "telepathy or psychic osmosis," symbols such as mudras or maṇdalas, sound (as in mantras), or symbolic language. ${ }^{95}$ However, no systematic comparison is sought after. Remarks such as that it "is only by dying on the Cross of Sangsāra that one attains life more abundantly,"96_ placing elsewhere Jesus Christ next to the Buddha as both being Theosophic "avataras" - or that "animal instinct, whereby the multitude are chiefly guided and through which they are controlled by the state, must be transcended," $" 97$ make it surely difficult for traditional historians of religion to take the work as unbiased scholarship.

the single (nature of) mind which encompasses all of Samsara and Nirvana" ("khor 'das yongs la khyab-pa'i sems gcig-po). This is its only occurrence.” Reynolds (Self-Liberation, 71-115) lists various other problems of Evans-Wentz' translation. For example, resorting to Hindu Tantric concepts, Evans-Wentz designates the consorts or female aspects of the Buddhas as "Shaktis," "Powers," "in this way reversing the polarity of the whole Buddhist system."

93 Evans-Wentz, The Tibetan Book of the Great Liberation, 7.

94 Evans-Wentz, The Tibetan Book of the Great Liberation, 9; cf. 10, 197-199.

95 Cf. Evans-Wentz, The Tibetan Book of the Great Liberation, 24.

96 Evans-Wentz, The Tibetan Book of the Great Liberation, 75.

97 Evans-Wentz, The Tibetan Book of the Great Liberation, 80. 


\section{Evans-Wentz' Contribution to the Comparative Study of Religion}

"W. Y. Evans-Wentz is a great scholar who devoted his mature years to the role of bridge and shuttle between Tibet and the west: like an RNA molecule activating the latter with the coded message of the former" - with these words, Timothy Leary, Ralph Metzner, and Richard Alpert praise "the work of this academic liberator" in their free adaption, The Psychedelic Experience. A Manual Based on the Tibetan Book of the Dead (1964). ${ }^{98}$ By the 1960, Evans-Wentz' translation of the Tibetan Book of the Dead had become an indispensable source for inspiration of various audiences. With the Book at hand, Theosophists and Spiritualists were convinced to have sufficient evidence for remarkable correspondences to Western occult views, proving not the least the transcultural prevalence of certain experiences of the disembodied soul in after-death realms, but also the principle teachings of the founding fathers and mothers of Theosophy. ${ }^{99}$ The influential writer and intellectual, Aldous Huxley, referred to Evans-Wentz' works in his writings, and had even made use of the Book as a guide for accompanying his dying wife. ${ }^{100}$ While the wide circulation of his books ensured Evans-Wentz many readers of a general audience, too, it is much more difficult to trace his influence on the emerging field of "comparative religion," or the "science of religion." On the one hand, scholars of religion that were attracted by C.G. Jung (who had written two introductory essays printed in Evans-Wentz' books), or adapted in some way or the other the approach of a transcultural "essence" in religion, quoted his works, but usually without mention of their view of an esoteric common core in the East and the West. Mircea Eliade, for example, refers to his studies, ${ }^{101}$ or Joseph Campbell, in his The Hero with a Thousand Faces, quotes from Evans-Wentz' Milarepa. ${ }^{102}$ Among scholars of (Tibetan) Mahāyāna and Vajrayāna of the 1950s and 1960, studies by Evans-Wentz were frequently mentioned, but with the respective works of such scholars as Guiseppe Tucci, Shashibhusan Dasgupta, and David L. Snellgrove (or, from the late 1960s onwards, Alex Wayman and others),

98 Cf. Schlieter, What is it like to be Dead? 200-202.

99 Cf. Schlieter, What is it like to be Dead? 163-165.

100 Cf. Schlieter, What is it like to be Dead? 183.

101 Mircea Eliade, Yoga: Immortality and Freedom (New York: Pantheon Books, 1958) refers to The Tibetan Book of the Dead, cf. 236, 246, 325, 331-333; 391-393, 431. Eliade refers also to Tibetan Yoga and Milarepa.

102 Cf. Joseph Campbell, The Hero with a Thousand Faces (1949 Princeton: Princeton University Press, 2004), 147-149. 
scholars entered the field that were not only to able to read Tibetan and Sanskrit. Yet, these scholars could, however, build on Evans-Wentz as one forerunner to overcome the earlier distinction between a "real" Buddhism and a "degenerate" Tantric Buddhism, but without adhering to his Theosophical preconceptions. ${ }^{103}$ In a way, Evans-Wentz' works succeeded in no longer depicting Buddhist Tantra as a weird monstrosity, a degeneration, or an aberration, which had largely been the view of various scholars of Buddhism in the late $19^{\text {th }}$ and early $20^{\text {th }}$ century (such as Friedrich Max Müller in his famous dictum that "there is nothing esoteric in Buddhism"104). In current studies of Tibetan Buddhism, however, Evans-Wentz' influence has almost vanished. Mostly, his works are mentioned shortly in their overview of earlier Western works on Kagyupa literature, Milarepa, or the Book. Yet, until most recently, new translation of the various scriptures that belong to the corpus of "The Great Liberation by Hearing in the Intermediate States" (bar do thos grol chen mo), as the Tibetan title has it, still pay a faint tribute to Evans-Wentz by using variants of the established title The Tibetan Book of the Dead. ${ }^{105}$

To conclude, it seems that Evans-Wentz can indeed best be portrayed as a religiously interested, enthusiastic scholar-practitioner who was caught between at least three different stools, and was accordingly to patronize. In the field of Tibetan Buddhist Studies, his limited philological skills were criticized, as were his Theosophical isogetical readings of Buddhist doctrines. For Theosophists, it seems that he was neither "orthodox" nor innovative enough to resume a more elevated position. In addition, his focus on Tibetan Buddhism (and not Indian traditions of Yoga favored by later Theosophy), and his lack of philological skills - in the Adyar branch, many Theosophists had knowledge of Sanskrit ${ }^{106}$ - were supposedly additional obstacles to his later reception in Theosophy.

For scholars of comparative religion, the absence of a theoretical reflection on the comparative enterprise, and the predilection for perennialist, pan-karmic rebirth theory, but also his religiously interested enthusiasm

103 Cf. Christian K. Wedemeyer, "Tropes, Typologies, and Turnarounds: A Brief Genealogy of the Historiography of Tantric Buddhism," History of Religions, 40, 3 (2001), 223-259. Christian K. Wedemeyer, Making Sense of Tantric Buddhism: History, Semiology, and Transgression in the Indian Traditions (New York: Columbia University Press, 2012).

104 Friedrich M. Müller, Life and Religion: And Aftermath from the Writings of the Right Honourable Professor F. Max Müller (New York: Doubleday, 1905), 218-219.

105 For example, Gyurme Dorje, The Tibetan Book of the Dead. 1st Comp. Trans. (New York: Penguin, 2006).

106 Cf. Yves Mühlematter, "Translation between Acceptance and Deviance. Translational Endeavors within the Theosophical Society. A Case Study of Annie Besant's Bhagavad Gita" (presentation at the ESSWE Conference in Erfurt unpublished). 
hindered a broader recognition. Paradoxically, while his works flourished and were read by a multitude, the author's achievements - apart from presenting the translations - were mostly considered to be not particularly noteworthy. Things would have looked different if Evans-Wentz would have been able to go beyond a culture-transcending "Occult Science" and to present a truly "comparative esotericism" of Tibetan Buddhism, Hindu Tantra, and Western occult traditions - a task that has, as of today, only in part been achieved.

\section{Bibliography}

Bhutia, Kalzang Dorjee. "Looking Beyond the Land of Rice: Kalimpong and Darjeeling as Modern Buddhist. Contact Zones for Sikkimese. Intellectual Communities." In Transcultural Encounters in the Himalayan Borderlands: Kalimpong as a 'Contact Zone', edited by Markus Viehbeck, 301-318. Heidelberg: Heidelberg University Publishing, 2017. Doi: 10.17885/heiup.301.409.

Bishop, Peter. Dreams of Power: Tibetan Buddhism and the Western Imagination. London: Athlone Press, 1993.

Campbell, Joseph. The Hero with a Thousand Faces. Princeton and Oxford: Princeton University Press, (1949), 2004.

Cuevas, Bryan J. The Hidden History of the Tibetan Book of the Dead. Oxford and New York: Oxford University Press, 2003.

Dorje, Gyurme. The Tibetan Book of the Dead. First Complete Translation. New York: Penguin, 2006.

Eliade, Mircea. Yoga: Immortality and Freedom, New York: Pantheon Books, 1958.

Evans-Wentz, Walter Yeeling. The Fairy-faith in Celtic Countries. London, New York: Oxford University Press, 1911.

_- "Some Notes for an Autobiography" (unpublished). Special Collection, Stanford University Libraries (Box 1, 20 fol.). Sikkim, 1920.

- The Tibetan Book of the Dead or the After-Death Experiences on the Bardo Plane, according to Lāma Kazi Dawa-Samdup's English Rendering. With a new Foreword and Afterword by Donald S. Lopez. Oxford: Oxford University Press, 2000. First published 1927 by Oxford University Press (Oxford)

Tibet's Great Yogĩ Milarepa. London: Oxford University Press, 1928.

—. Tibetan Yoga and Secret Doctrines. London: Oxford University Press, 1935.

—. Cuchama and Sacred Mountains, edited by Frank Waters and Charles L. Adams.

Chicago, Swallow Press; Athens, Ohio: Ohio University Press, 1981.

Hammer, Olav. Claiming Knowledge: Strategies of Epistemology from Theosophy to the New Age. Leiden \& Boston: Brill, 2004.

—. and Mikael Rothstein, eds. Handbook of the Theosophical Current. Leiden \& Boston: Brill, 2013.

Kovács, Iván. “The Tibetan Tetralogy of W. Y. Evans-Wentz: A Retrospective Assessment.” Two Parts. The Esoteric Quarterly, Winter 2015: 15-33; Spring 2015: 65-79.

Leary, Timothy, Ralph Metzner, and Richard Alpert. The Psychedelic Experience: A Manual Based on the Tibetan Book of the Dead. Secaucus, NJ: Citadel Press, 1964. 
Lopez, Donald S. Jr. The Tibetan Book of the Dead: A Biography. Oxford \& Princeton, NJ:

Princeton University Press, 2011.

McGuire, William. Jung, Evans-Wentz and Various Other Gurus. Journal of Analytical Psychology 48 (2003): 433-445.

Mühlematter, Yves. "Translation between Acceptance and Deviance: Translational Endeavors within the Theosophical Society; A Case Study of Annie Besant's Bhagavad Gita." Presentation at the ESSWE Conference in Erfurt, unpublished.

Müller, Friedrich Max. Life and Religion: And Aftermath from the Writings of the Right Honourable Professor F. Max Müller. New York: Doubleday, 1905.

Nahm, Michael. "The Tibetan Book of the Dead: Its History and Controversial Aspects of Its Contents." Journal of Near-Death Studies 29 (3) 2011: 373-398.

Nutt, Alfred. The Voyage of Bran, Son of Febal, to the Land of the Living: An old Irish Saga; With an Essay upon the Irish Vision of the Happy Otherworld and the Celtic doctrine of Rebirth. London: D. Nutt, 189597.

Reynolds, John Myrdhin. Self-Liberation through Seeing with Naked Awareness. Barrytown, N.Y.: Station Hill Press, 1989.

Rimbach-Sator, Friedemann. “'Esoteric Fairy Faith:' The Theosophical Background of Walter Y. Evans-Wentz's The Fairy Faith in Celtic Countries." Master's thesis, University of Amsterdam, 2018.

Schlieter, Jens. What is it like to be Dead. Near-death Experiences, Christianity, and the Occult. New York: Oxford University Press, 2018.

Sinnett, Alfred Percy. Esoteric Buddhism. 5th enl. ed. London: Chapman and Hall, 1885. First published 1883 by Trübner \& Co. (London).

- The Occult World. 2nd Am. Ed. Boston: Houghton, Mifflin, and Co., 1885.

Strong, John. "Tensions in the Field of Religious and Buddhist Studies." In Teaching Buddhism: New Insights on Understanding and Presenting the Traditions, edited by Todd Lewis, Gary DeAngelis, ix-xi. New York: Oxford University Press, 2016.

Wedemeyer, Christian Konrad. "Tropes, Typologies, and Turnarounds: A Brief Genealogy of the Historiography of Tantric Buddhism," History of Religions 40, 3 (2001): 223-259.

- Making Sense of Tantric Buddhism: History, Semiology, and Transgression in the Indian Traditions. New York: Columbia University Press, 2012.

Winkler, Ken. Pilgrim of the Clear Light: The Biography of W.Y. Evans-Wentz. 2nd ed. Middletown: Booksmango, 2013. 